\title{
Determining the Critical Success Factors for Highway Construction Projects in Pakistan
}

\author{
Samiullah Sohu \\ Department of Civil Engineering \\ Quaid-e-Awam University College of \\ Engineering, Science \& Technology \\ Larkano, Sindh, Pakistan \\ sohoosamiullah@gmail.com
}

\author{
Ashfaque Ahmed Jhatial \\ Department of Civil Engineering \\ Mehran University of Engineering and \\ Technology, SZAB Campus \\ Khairpur Mirs, Sindh, Pakistan \\ aajhatial@hotmail.com
}

\author{
Kaleem Ullah \\ Faculty of Civil and Environmental \\ Engineering \\ Universiti Tun Hussein Onn Malaysia \\ Parit Raja, Johor, Malaysia \\ gf150051@siswa.uthm.edu.my
}

\author{
Muhammad Tahir Lakhiar \\ Faculty of Civil and Environmental Engineering \\ Universiti Tun Hussein Onn Malaysia \\ Parit Raja, Johor, Malaysia \\ gf170030@siswa.uthm.edu.my
}

\author{
Jam Shahzaib \\ Department of Civil Engineering \\ Quaid-e-Awam University College of Engineering \\ Science \& Technology \\ Larkano, Sindh, Pakistan \\ jam_shahzaib@hotmail.com
}

\begin{abstract}
The success of construction projects is not only crucial to stakeholders but also for the country's economic and social development. Critical success factors (CSFs) are considered as key to project management practices wich can lead to a construction project success. The aim of this research is to determine and rank the CSFs of highway construction projects in Pakistan. A deep literature review was carried out to determine a set of CSFs for construction projects. After that, a questionnaire based on found CSFs was designed and distributed among construction experts working in highway construction projects of Pakistan. Out of 250 distributed questionnaires, 130 were received completed and validated. Gathered data was analyzed through statistical software SPSS, and critical success factors were ranked based on their mean value. As a result, experienced project management team, effective site management, commitment of all parties to the project, experienced design team, and proper project planning have been determined as the top five critical success factors for highway projects in Pakistan. The findings of this research would help construction practitioners in understanding CSFs and to improve project performance.
\end{abstract}

Keywords-critical; success; factors; highway; construction; projects; Pakistan

\section{INTRODUCTION}

A vibrant construction industry plays a vital role in the economic growth and social development of any country. However, due to its complex nature and other uncertainties, construction projects are experiencing several problems and the highway projects of Pakistan are no exception. For productive construction industry, project success is essential [1]. Project success can also be defined as "When a project achieves more results than the excepted or normally obtained in terms of quality standards, cost, time, and safety measures" [1]. A construction project is considered successful when the project is completed on schedule time, within planned budget and satisfying quality standards [2]. There are many factors which influence the project performance and can lead to construction project success. According to [3] there are certain factors which are more important than others and are called "critical success factors". Author in [4] used the term critical success factors (CSFs) in projects management perspective for the first time and defined it as "CSFs are the few main areas of activity in which auspicious results are definitely compulsory for a particular manager to reach his or her goals". CSFs directly affect the main parameters which measures project success i.e. cost, time, quality and safety. Authors in [5] state that CSFs are helpful in productive decision making. Thus, determining and ranking of CSFs of construction project is important. The aim of this research is to determine and rank CSFs of highway construction projects. Most construction projects including highways projects in Pakistan are facing problems of delay [6, 7], cost overrun [8,9], quality [10] and failure in safety performance [11]. This research has focused CSFs of highway construction projects in Pakistan. The results of this research can influence success of highway construction projects.

\section{OBJeCTIVES}

1) To determine CSFs of highway construction projects in Pakistan.

2) To rank CSFs of highway construction projects applying their mean values.

\section{LITERATURE REVIEW}

In previous researches, a number of factors influencing the success of the construction projects project were identified. 
Authors in [12] studied the CSFs of construction projects in Thailand. A questionnaire based on CSFs grouped into nine categories was distributed among construction practitioners. The survey results showed that proficiency of project management team, proper quality control, good relationship among project members, regular maintenance of equipment required for the project, capable supervisors, effective communication among project stakeholders, and durability of the completed work were the most CSFs in each category. Authors in [13] investigated the CSFs of public-private partnership highway project in Malaysia. The study was carried out through conducting interviews with ten public sector clients working in highways projects and through a real case study of highway project. The top five CSFs were effective communication, proper project planning and commitment from public and private sectors, fair procurement process and potential to delegate authority. Authors in [14] discussed the CSFs for construction projects in Iran. A literature based questionnaire was designed. Questionnaire was prepared with respect to project success criteria measures i.e. time, cost, quality and safety and was distributed to construction experts. The findings of the study showed that efficient project planning, allocating suitable finance, multidisciplinary project team, adequacy of resources required for project, effective project monitoring, qualified and experienced project management team, tender awarded to competent contractors, the urgency of completing the project, correct and reliable estimates of project costs, clear contracts and project goals, and support from senior management of the project were the dominant CSFs. Another research in Iran [15], found that availability of resources, skilled project management team, strategic project planning, on-time decision making, and effective project monitoring were the top CSFs for construction projects. In Libya, authors in [16] investigated the most CSFs of construction projects. The research was conducted through quantitative approach by distributing questionnaires in construction professionals from both public and private sector. Research concluded that efficient project monitoring, effective coordination, timely decision making, proper site management, and experienced design team are the main factors influencing project success. Author in [17] obtained the CSFs for large construction projects through conducting interviews with project managers from four Nordic countries. The findings of the study showed that experienced project management team, availability of resources, and effective communication were main CSFs of large construction projects. Authors in [18] studied CSFs for public private projects in UK construction industry using a questionnaire survey comprised of 18 CSFs. Factor analysis revealed that strong private consortium, proper risk allocation and risk sharing, availability of finance, commitment of both public/private sectors, and competitive procurement process are the main CSFs. Authors in [3] studied construction CSFs in Pakistan by applying a quantitative approach. The main CSFs were proper communication system, effectiveness of decision making, experienced project management team, skillful contractors, effective supervision, and proper planning.

From the literature review the following CSFs were identified: experienced project management team, effective site management, effective communication and coordination, commitment of all parties to the project, on time decision making, good relationship among project participants, experienced design team, availability of resources required for project, effective quality control system, adequacy of raw materials, allocating appropriate funds, availability of equipment, capable supervisors, experienced sub-contractors, use of environment friendly equipment, support from senior management, implementation of safety management system, regular equipment maintenance, utilization of advanced technology, clear project goals, proper project planning, competitive procurement process, multidisciplinary project team, and correct estimation of project cost.

\section{RESEARCH METHOD}

In this research both literature review and field survey were used to gather data. Literature review resulted in the identification of 24 CSFs. A questionnaire containing these 24 CSFs was design, consisting of two parts. Part A aimed to know the demography of survey participants while Part B aimed to get the perception of construction professionals on CSFs for highway projects in Pakistan. Five-point Likerd scale was used to assess the CSFs from 1 for "Not significant" to 5 for "Extremely significant". Before the questionnaire survey, content analysis of the designed questionnaire was carried out. For content analysis the questionnaire was checked with five construction experts of highway projects. The experts were asked whether CSFs given in the questionnaire were relevant to highway projects or not. According to them, all proposed CSFs provided were relevant. After content analysis the questionnaire was disturbed to 250 construction professionals of highway projects in Pakistan.

\section{DATA ANALYSIS AND DISCUSSION}

A total of 130 completed questionnaires were collected, showing a response rate of $52 \%$. Respondents of the questionnaire survey were from different organization backgrounds. Figure 1 shows the results of the survey participants based on their organizations. The majority of the survey respondents are from clients (50) followed by contractors (44). Only $28 \%$ of the survey respondents were from the consultants group. Respondents experience and educational level are important aspects in questionnaire survey. Figure 2 shows the academic qualification of the exports participated in the surrey. A large number of participants (i.e. 70 of 130) have obtained bachelor degree. Thirty-five respondents of the survey had master's degree and twenty-five 25 had diploma degree. Overall survey respondents had sufficient education level. Apart from education level, experience of the respondents in highway projects is vital in deciding the critical success factors for highway projects. Figure 3 shows the experience of survey participants in highway projects. Collected data were analyzed using SPSS. Cronbach's alpha was used to measure the internal consistency, to know how well the items in the questionnaire are correlated to each other. It is suggested that Cronbach's alpha value is strong if more than or equal to 0.7 [19]. The Cronbach's alpha of this research is 0.785 , showing acceptable internal consistency of the survey instrument. The critical success factors were ranked based on their mean value. CSF ranking 
enabled the identification of the main CSFs of highway projects in Pakistan. Table I shows the ranking of the CSFs of highway projects in Pakistan.

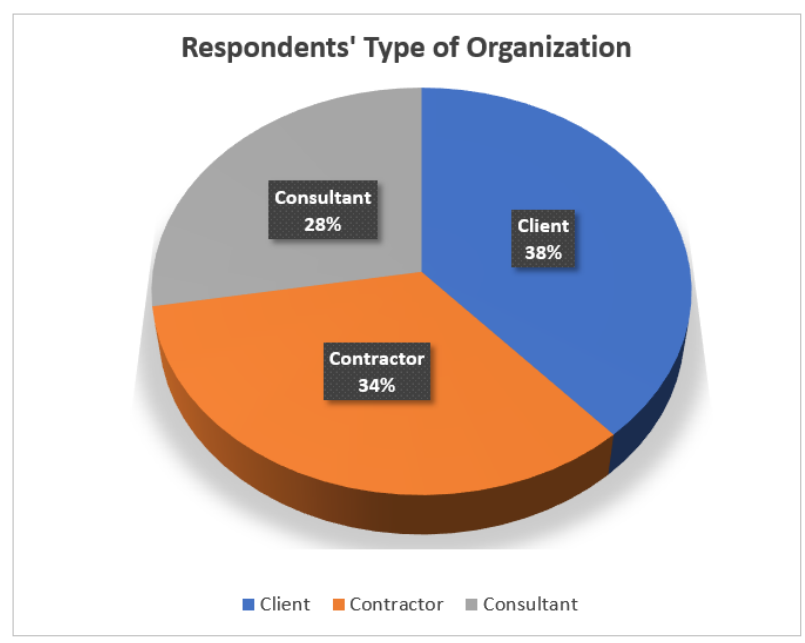

Fig. 1. Type of respondents' organization

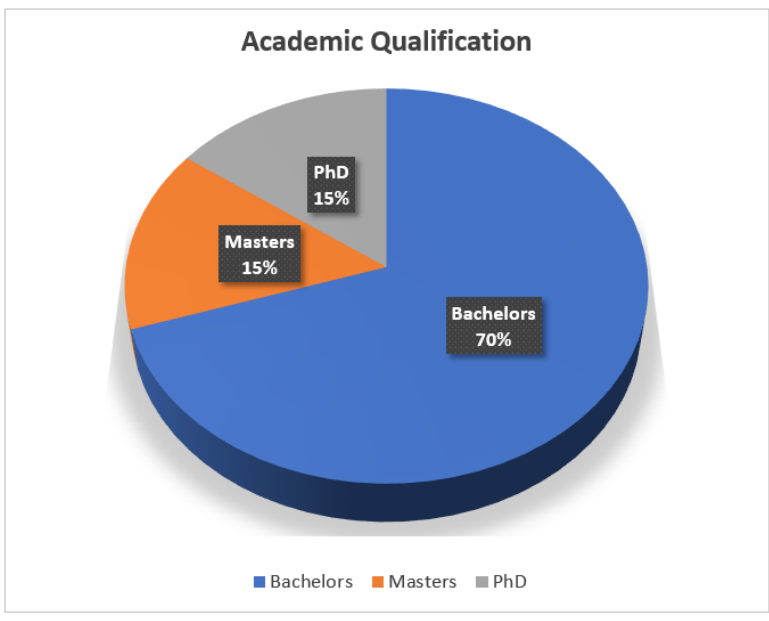

Fig. 2. Respedents' academic qualification

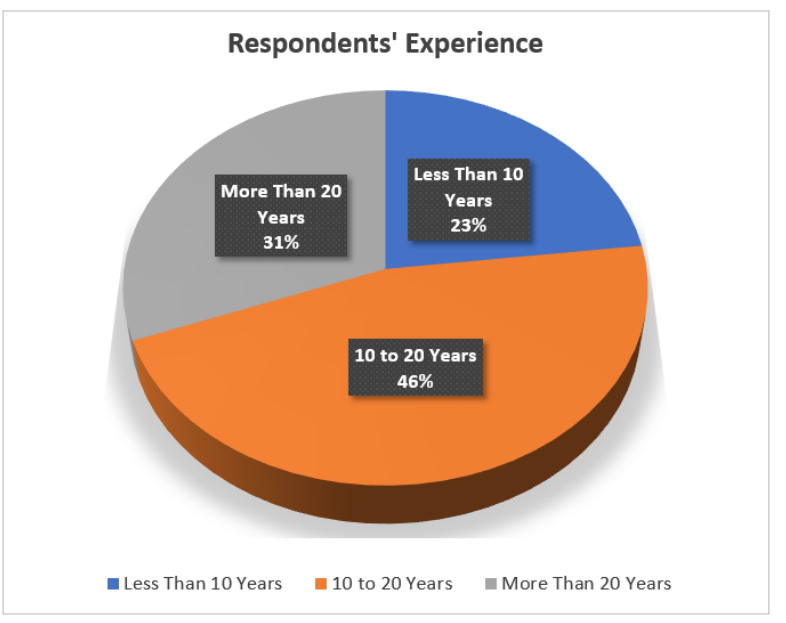

Fig. 3. Respondent's experience
TABLE I. CSFS RANKING

\begin{tabular}{|c|c|c|}
\hline Critical Success Factors & Mean Value & Ranking \\
\hline Experienced project management team & 4.54 & 1 \\
\hline Effective site management & 4.50 & 2 \\
\hline Commitment of all parties to the project & 4.46 & 3 \\
\hline Experienced design team & 4.31 & 4 \\
\hline Proper project planning & 4.25 & 5 \\
\hline $\begin{array}{l}\text { Effective communication and } \\
\text { coordination }\end{array}$ & 4.19 & 6 \\
\hline Allocating appropriate funds & 4.10 & 7 \\
\hline Equipment availability & 3.94 & 8 \\
\hline Effective quality control system & 3.92 & 9 \\
\hline Availability of resources & 3.90 & 10 \\
\hline $\begin{array}{c}\text { Implementation of safety management } \\
\text { system }\end{array}$ & 3.83 & 11 \\
\hline Experienced sub-contractors & 3.82 & 12 \\
\hline Adequacy of raw materials & 3.59 & 13 \\
\hline Capable supervisors & 3.57 & 14 \\
\hline Competitive procurement process & 3.54 & 15 \\
\hline $\begin{array}{c}\text { Good relationship among project } \\
\text { participants }\end{array}$ & 3.52 & 16 \\
\hline On time decision making & 3.50 & 17 \\
\hline Multidisciplinary project team & 3.48 & 18 \\
\hline Correct estimate of project cost & 3.46 & 19 \\
\hline Clear project goals & 3.45 & 20 \\
\hline Support from senior management & 3.32 & 21 \\
\hline Utilization of advanced technology & 3.25 & 22 \\
\hline Use of environment friendly equipment & 3.21 & 23 \\
\hline Regular equipment maintenance & 3.14 & 24 \\
\hline
\end{tabular}

Table I shows respondents ranked the "experienced project management team" as the most significant with mean value of 4.50. Experienced project management team is key to project success. Effective site management ranked 2 nd, followed by "commitment from all participants of project" with mean scores 4.50 and 4.46 respectively. The respondents ranked "experienced design team" as fourth significant CSF. Design team plays an important role as their work involves from beginning to completion on a project. Competent designers can influence success of construction projects. Utilization of advanced technology, use of environment friendly equipment, and regular equipment maintenance ranked next.

\section{CONCLUSION}

The quality completion of highway construction projects within cost and time is the top priority for the stakeholders. In this research, CSFs of highway projects have been studied. The most important CSFs found to be experienced project management, effective site management, commitment of all parties to the project. The scope of this research is limited to highway projects in Pakistan. The results of this research can contribute construction professionals to achieve successful projects.

\section{REFERENCES}

[1] N. Ramlee, N. J. Tammy, R. M. Noor, A. A. Musir, N. A. Karim, H. B. Chan, S. R. M. Nasir, "Critical Success Factors For Construction Project", AIP Conference Proceedings, Vol. 1774, No.1, pp. 030011-1030011-7, 2016

[2] A. P. C. Chan, D. Scott, E. W. M. Lam, "Framework of Success Criteria for Design/Build Projects", Journal Of Management In Engineering, Vol. 18, pp. 120-128, 2002 
[3] M. Saqib, R. U. Farooqui, S. H. Lodi, "Assessment of Critical Success Factors for Construction Projects in Pakistan", First International Conference on Construction In Developing Countries, Karachi, Pakistan, pp. 392-404, August 4-5, 2008

[4] J. F. Rockart, "The changing role of the information systems executive: A critical success factors perspective", Sloan Management Review, Vol. 24, No. 1, pp. 3-13, 1982

[5] Z. Alias, E. M. A. Zawawi, K. Yusof, A. Abra, "Determining Critical Success Factors of Project Management Practice: A conceptual framework", Procedia-Social and Behavioral Sciences, Vol. 153, pp. 6169, 2014

[6] S. Sohu, N. A. Memon, S. A. Abbasi, M. A. Pahore, K. Ullah, "Causes of Delay in Highway Projects in Pakistan", 8th International Civil Engineering Congress, Karachi, Pakistan, pp. 35-40, December 23-24, 2016

[7] S. Haq Y. Rashid, M. S. Aslam, "Effects of Delay in construction Projects of Punjab-Pakistan : An Empirical Study", Journal of Basic and Applied Scientific Research, Vol. 4, No. 4, pp. 98-104, 2014

[8] I. Zafar, T. Yousaf, S. Ahmed, "Evaluation of Risk Factors Causing Cost Overrun in Road Projects in Terrorism Affected Areas Pakistan-a Case Study", KSCE Journal of Civil Engineering, Vol. 20, No. 5, pp. 16131620,2016

[9] A. R. Nasir, H. F. Gabriel, R. M. Choudhry, "Cost and Time Overruns in Highway Projects of Pakistan", Sixth International Conference on Construction in the 21st Century, Kuala Lumpur, Malaysia, pp. 69-76, 2011

[10] M. Abas, S. B. Khattak, I. Hussain, S. Maqsood, I. Ahmad, "Construction Projects Evaluation of Factors affecting the Quality of Construction Projects", Technical Journal, University of Engineering and Technology, Vol. 20, No. 2, pp. 115-120, 2015

[11] R. Farooqui, F. Arif, S. F. A. Rafeeqi, "Safety Performance in Construction Industry of Pakistan", First International Conference on Construction In Developing Countries, Karachi, Pakistan, pp. 74-87, August 4-5, 2008

[12] S. Homthong, W. Moungnoi, "Critical Success Factors Influencing Construction Project Performance for Different Objectives: Operation and Maintenance Phase", International Journal of Advances in Mechanical and Civil Engineering, Vol. 3, No. 3, pp. 84-95, 2016

[13] F. E. M. Ghazali, S. A. Rashid, A. M. Sadullah, "The Critical Success Factors for Public-Private Partnership Highway Construction Project in Malaysia". Journal of Engineering and Technology, Vol. 8, No. 1, pp. 69-84, 2017

[14] A. I. Maghsoodi, M. Khalilzadeh, "Identification and Evaluation of Construction Projects ' Critical Success Factors Employing FuzzyTOPSIS Approach", KSCE Journal of Civil Engineering, pp. 1-13, 2017

[15] A. Pakseresht, "Determining the Critical Success Factors in Construction Projects: AHP Approach", Interdisciplinary Journal of Contemporary Research in Business, Vol. 4, No. 8, pp. 383-393, 2012

[16] A. Omran, M. A. Abdulbagei, A. O. Gebril, "An Evaluation of the Critical Success Factors for Construction Projects in Libya", Journal of Economic Behavior, Vol. 2, pp. 17-25, 2012

[17] H. Szentes, "Success Factors in Large Construction Projects", Proceedings of TG65 and W065-Special Track. 18th CIB World Building Congress, pp. 423-433, 2010

[18] B. Li, A. Akintoye, P. J. Edwards, C. Hardcastle, "Critical success factors for PPP / PFI projects in the UK construction industry", Construction Management and Economics, Vol. 23, No. 5, pp. 37-41, 2005

[19] M. S. Litwin, A. Fink, How to Measure Survey Reliability and Validity, Thousand Oaks, Sage, 1995 